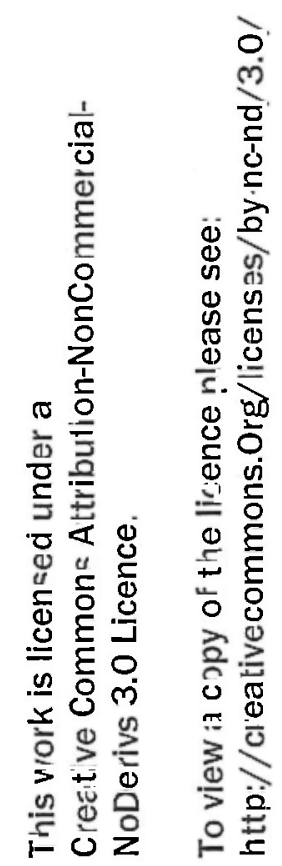




\section{INSTITUTE}

FOR

DEVELOPMENT STUDIES

\section{UNIVERSITY COLLEGE, NAIROBI}

\section{THE EFFORT TO FEDERATE EAST AFRICA :}

\section{A POST-MORTEM}

by

J. H. Proctor, Jr. Duke University

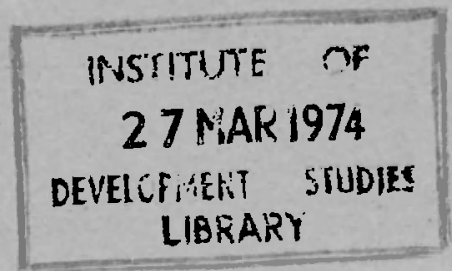

Reprint Series: No. I4

Reprinted for private circulation from the

Political Quarterly Vol. 7, No. I, (January-March, I966)

with the permission of the Editors. 


\section{REPRINT SERIES}

1. P. Robson: Stagnation or Growth for East Africa?

2. D. M. Etherington: Land Settlement in Kenya; Policy and Practice.

3. D. A. Lury: National Accounts in Africa.

4. J. E. Price: International Burden-Sharing.

5. C. W. Howe \& H. Karani: A Projection Model for the Kenya Economy.

6. D. M. Etherington: Projected Changes in Urban and Rural Population in Kenya and the Implication for Development Policy.

7. M. Gaskin: Monetary Flexibility in Dependent Economies.

8. C. A. Cooper and B. F. Massell: Toward a General Theory of Customs Unions for Developing Countries.

9. P. Robson: The Problem of Senegambia.

10. C. A. Cooper and B. F. Massell: A New Look at Customs Union Theory.

11. J. H. Proctor: The Role of the Senate in the Kenya Political System.

12. J. H. Proctor and K. G. V. Krishna: The East African Common Services Organization: An Assessment.

13. D. A. Lury: The Trade Statistics of the Countries of East Africa 1945-1964 and African Population Estimates: Back Projections of Recent Census Results.

14. J. H. Proctor, Jr.: The Effort to Federate East Africa: A PostMortem.

15. D. A. Lury \& A. A. Shah: Local Government in Kenya: Income and Expenditure 1959-1961.

16. William Barber: Some Questions about Labour Force Analysis in Agrarian Economies with Particular Reference to Kenya.

17. J. Heyer: Kenya's Cautious Development Plan.

Reprints may be obtained from:

The Secretary,

The Institute for Development Studies,

University College, Nairobi,

P.O. Box 30197,

Nairobi.

Any views expressed in this paper are those of the author. They should not be interpreted as reflecting the views of the Institute for Development Studies or of the University College, Nairobi. 
Reprinted from

POLITICAL QUARTERLY

January 1966

by The Eastern Press, Ltd., London and Reading 


\title{
THE EFFORT TO FEDERATE EAST AFRICA: A POST-MORTEM
}

\author{
J. H. PROCTOR, JR.
}

EAST Africa has been generally regarded as the section of that continent where a federal movement would be most likely to succeed. Kenya, Tanganyika and Uganda displayed striking similarities in political institutions and ideas as they emerged from British rule, and a substantial measure of inter-territorial economic integration had been achieved through the East African Common Services Organisation (EACSO), a common market and a common currency. With the transfer of power to African hands, the chief obstacle to earlier efforts at closer political association-the fear of extending the influence of Kenya's white settlers throughout the area-was eliminated.

\section{The Declaration of Intent to Federate}

It was not surprising, therefore, when the heads of the three Governments solemnly declared in Nairobi on June 5, 1963, their intention to create an East African Federation; and their pledge to attain that goal by the end of the year did not seem altogether unreasonable. A Working Party was being established to draft the federal constitution, they announced, and its proposals would be considered by a full-scale conference in the third week of August.

Federation did not in fact materialise in 1963, and although there were strong indications during the following year that no real progress was being made in that direction, most East African politicians continued to talk-publicly, at least-as if agreement would be reached fairly soon. By June 1965, however, it was clear to all concerned that federation was no longer a live issue and that, indeed, the most that could be hoped for would be to hold together some of the existing arrangements for economic co-operation.

It is not too early to attempt at least a preliminary inquiry into the causes of this failure. The full record of the federal negotiations has not yet been made available, but it is possible to define the key differences which arose in the Working Party on the basis of partial disclosures by some of its members, and the more basic underlying

- The author has recently spent fifteen months teaching and doing research in East Africa. $\mathrm{He}$ is Associate Professor of Political Science in Duke University, North Carolina. 
THE EFFORT TO FEDERATE EAST AFRICA: A POST-MORTEM

difficulties can be identified from an analysir of Government publications and local Press reports since the Nairobi Declaration.

\section{I}

The Working Party, which consisted mainly of Ministers from the three territories, held its first meeting in Dar es Salaam on June 9 and 10,1963. Negotiations apparently proceeded very smoothly. The Kenyan Minister for Justice and Constitutional Affairs, Mr. T. J. Mboya, reported that they had "fully examined all points relating to the constitution " and had " reached agreement on every issue" 1 and none of the other members contradicted him. The legal advisers had been instructed, he added, to outline an initial draft for consideration by the group at its next session in Kampala on June 29, and the United Nations had been requested to supply specialists to assist on financial and public service matters.

At Kampala, the Working Party not only discussed the lawyers' draft at length, but also met with the three Heads of Government and with several of Uganda's hereditary rulers. Mr. Mboya again gave the Press a highly optimistic account of what was accomplished. The talks had gone so well, he said, that the full federal conference might take place earlier than originally planned; the lawyers were preparing a revised constitutional draft which the Working Party would examine on July 15 in Nairobi. ${ }^{2}$ Actually, however, very serious differences emerged on this occasion. The Ugandan delegation, which had been given a new chairman after the first meeting, refused to accept the decisions which had been made at Dar es Salaam and no compromise could be found between the stand it now took on several fundamental questions and the views of Kenya and Tanganyika.

Agreement proved impossible at the Nairobi session as well, so it was decided that each delegation should consult with its Government and then prepare for circulation to the others a memorandum stating in detail its position on the unresolved issues. There was still no official indication that the negotiations had run into difficulty. In fact, Mr. Mboya assured the Kenyan House of Representatives on August 2 that matters were proceeding "very satisfactorily" and that the constitution would be produced " within the next ten days or so ".

The memoranda revealed no significant change in the position of

1 Tanganyika Standard (Dar es Salaam), June 11, 1963.

2 East African Standard (Nairobi), July 3, 1963.

3 Kenya House of Representatives, Official Report, August 2, 1963, col. 1670. 
J. H. PROCTOR, JR.

any of the delegations and the Working Party found itself still deadlocked when it reconvened in Dar es Salaam on August 9. The group decided, therefore, to make a full report on the impasse to the heads of Government and to ask them for fresh directives. For public consumption, it was announced by Mr. Oscar Kambona, the Tanganyikan Foreign Minister, that they had " covered a very wide area of agreement in spite of a few issues on which there was a difference of opinion among delegations", and that a meeting of the heads of Government would be held within a few days at which he was "very hopeful " that the differences would be resolved."

Uganda soon informed the others, however, that it would not take part in a summit conference until the Working Party's report had been considered by each of the Governments; and Mr. A. A. Nekyon, the Minister of Planning and Community Development and the head of its delegation, stated that such consideration would take so long that it seemed to him "practically impossible to have Federation this year ".

The meeting of the three heads of Government was finally scheduled for September 19 at Nairobi; but at the last moment the Ugandan Prime Minister, Dr. Milton Obote, decided not to attend, allegedly because of illness, and it had to be postponed. Shortly thereafter, Mr. Joseph Murumbi, the Kenyan Minister of State with responsibility for external relations and a member of the Working Party, publicly expressed doubts about the possibility of including Uganda in the federation and indicated that Kenya and Tanganyika might have to unite alone initially. ${ }^{6}$ When Dr. Obote demanded to know whether Mr. Murumbi was expressing official Kenyan policy, the Prime Minister, Mr. Jomo Kenyatta, replied that he had voiced only his own personal views, and invited Dr. Obote to name a date for a meeting of the heads of Government.

It was not until January 14, 1964, that the three top leaders actually came together. At that session, Dr. Julius Nyerere, the President of Tanganyika, expressed grave concern over the economic disadvantages which his country was suffering from the continued operation of the common market without federation. Dr. Obote reportedly "explained very frankly the political difficulties he was facing on the issue of Federation ... [ [and] suggested that the next step should be to concentrate on the economic aspects of closer

4 Tanganyika Standard, August 12, 1963.

5 Uganda Argus (Kampala), August 21, 1963.

- East African Standard, October 25, 1963. 
THE EFFORT TO FEDERATE EAST AFRICA: A POST-MORTEM

association ". They and Mr. Kenyatta could agree merely to instruct their Ministers or Directors in charge of economic planning to examine jointly "certain problems connected with economic development which need to be sorted out urgently for the harmonious development of the three states ". ${ }^{8}$

When those officials met two months later, Tanganyika put forward such drastic proposals for redressing the imbalance in its trade with Kenya and Uganda that the other two simply reported back to their Governments and a further summit meeting was promptly arranged. It was widely rumoured that Tanganyika was threatening to establish a separate currency and to withdraw from the common market unless federation could be quickly achieved. Each of the heads of Government was accompanied by a strong ministerial team when they met in Nairobi on April 10 and 11. Dr. Nyerere pressed for immediate federation, but secured only an agreement that the Working Party should make a further attempt to resolve the outstanding differences and that an Emergency Committee should be set up to examine Tanganyika's economic proposals. That committee subsequently recommended a quota system for interterritorial trade and a scheme for allocating industries among the three states, which were accepted by the Governments.

\section{Backbench Impatience}

Meanwhile, there were signs of growing impatience among backbenchers in Kenya. On April 9 the Parliamentary Group of the ruling Kenya African National Union (KANU) passed a resolution expressing concern over the possibility of a breakdown in the federal negotiations and calling for an early meeting of Government backbenchers in all three territories to accelerate federation. The Tanganyika African National Union (TANU) Parliamentary Group heeded the call and sent nine representatives to Nairobi for a conference on May 7, but the Ugandans declined to participate.

The conference called upon the three Heads of Government to sign before May 20 a declaration that their countries should federate "forthwith", that they would meet again within fifteen days to sign "the interim articles of Federation", and that these articles should be ratified by the National Assemblies no later than June 16, $1964 .^{\ominus}$ Should Uganda not agree to such a course of action, the

7 United Republic of Tanganyika and Zanzibar National Assembly, Official Report, June 23, 1964 , col. 348 (O. S. Kambona).

- East African Standard, January 15, 1964.

- Ibid. May 11, 1964. 


\section{J. H. PROCTOR, JR.}

backbenchers resolved, Kenya and the United Republic of Tanganyika and Zanzibar should proceed to federate alone.

Delegations were dispatched to present these resolutions personally to each of the three Heads of Government. The one which called upon President Nyerere was warmly received; he told them: "I state quite categorically that the Government of the United Republic and myself are fully committed to entering immediately into a Federation with Kenya and Uganda, or with Kenya, or Uganda, alone ". ${ }^{10}$ Dr. Obote, on the other hand, informed the delegation to Kampala that he did not agree with the resolutions and would not attend the proposed meetings. He said that they were trying to force federation before many important issues had been settled, and that Uganda would not be pushed. ${ }^{11} \mathrm{Mr}$. Kenyatta told the conference delegation that he wanted all three territories to federate, not just two. In a television statement, he denied that there had been undue delay in the formation of a federation and asserted that the heads of Government " have been working for federation in a brotherly atmosphere " that none had rejected it, and that all were "keen to go ahead". He termed the resolutions "ill-timed" and the suggestion that Kenya and the United Republic might federate alone " most unfortunate". ${ }^{12}$

A further-and final-session of the Working Party took place in Kampala from May 30 to 31 . On this occasion, concessions were made by Kenya and the United Republic to the Ugandan demands on some points, and Mr. Nekyon told the Press that "great improvements had been made ... and there were now far fewer outstanding problems". ${ }^{13} \mathrm{He}$ anticipated that another summit conference would be held to settle the matters which remained in controversy after the three Governments had examined the Working Party's report. These rather optimistic comments prompted the United Republic to publish that report immediately, lest the public be completely misled. "The differences which have emerged in the Working Party's discussions ... are so fundamental ", it stated, "that the East African people should be taken into confidence immediately by providing them with an accurate report." ${ }^{14}$ This

10 "The President's Reply to the Delegation from the Nairobi Meeting of Representatives of the KANU and TANU Parliamentary Groups, 10.5.64", Meetings and Discussions on the Proposed East Africa Federation (Dar es Salaam: Information Services of the United Republic of Tanganyika and Zanzibar, September 1964), p. 20.

11 Uganda Argus, May 11, 1964.

12 East African Standard, May 12, 1964.

13 Uganda Argus, June 1, 1964.

14 "Government Statement on the East Africa Federation, June 1, 1964 ", Meetings and Discussions of the Proposed East African Federation, p. 6. 
THE EFFORT TO FEDERATE EAST AFRICA: A POST-MORTEM

report revealed, in fact, that the Ugandan Minister of Internal Affairs, Mr. F. K. Onama, had stated the view or his delegation to be that federation was not feasible and that attention should be shifted to strengthening EACSO.

In an effort to revive negotiations, the Kenyan House of Representatives passed on June 18 by a vote of 59-28 over the Government's objections a resolution requesting that Instruments of Federation be ratified by August 15, 1964; and four days later the Parliament of the United Republic unanimously approved a motion calling for immediate federation with either or both of the other two territories.

Uganda was unmoved, however. On June 26, the National Assembly there considered an Opposition resolution urging the Government to clarify its position on federation, and the Ministers who participated in the debate were clearly unwilling to proceed with the project for the present. As Dr. Obote departed from Entebbe for a meeting of the EACSO Authority in Nairobi on that same day, he emphasised to the Press that he was not going there to discuss federation and asserted that the Kenyan and United Republic resolutions would have no effect whatever on the decisions to be made by Uganda. ${ }^{15}$

Two days before the deadline set by the Kenyan House, Mr. Kenyatta issued a statement to the effect that he had been unable to consult with the other two leaders on federation because of the recent London and Cairo conferences, but that his Government would study the Working Party's report " with a view to continuing discussions with the other East African Governments". He offered his assurances that "everything will be done to expedite the establishment or formation of an East African Federation ". ${ }^{16}$

\section{Friction and Dissent Among the Governments}

There was no evidence of any advance towards that goal in the following months, however. Indications were, instead, that the three territories were moving further apart. The May 1965 session of the EACSO Central Legislative Assembly (CLA) was suspended indefinitely after acrimonious exchanges between its members which were sparked by Kenya's seizure of a Ugandan arms shipment being transported without authorisation across its territory from Dar es Salaam. More ominously, the next month Tanzania announced that

15 Uganda Argus, June 27, 1964.

16 "Statement by the Kenya Government on the East African Federation", Sessional Paper No. 5 of $1964 / 65$, August 13, 1964. 


\section{J. H. PROCTOR, JR.}

it was withdrawing from the currency union. This action was most probably prompted by Dr. Nyerere's conclusion that federation was no longer a practical possibility. It might conceivably have been designed to shock the others into reopening negotiations on the federal constitution, but it certainly did not have that effect. Mr. Onama told the Ugandan Assembly that unless Kenya and Tanzania accepted the conditions which he and Mr. Nekyon had laid down at the last Working Party meeting, "they will keep crying until the heavens fall ". ${ }^{17}$ "There was widespread apprehension that the actual effect would be to bring on the disintegration of the common market and the common services.

\section{II}

The failure to achieve an East African Federation may be attributed in the first instance to the inability of the three Governments to agree on the provisions of a federal constitution, and some insight into the problem can be gained from an analysis of the disputes which divided the Working Party.

\section{Differences Over the Constitution}

One issue which could not be settled was the site of the federal capital. At its first meeting, the Working Party agreed on Moshi, Tanganyika; but when Mr. Nekyon appeared as the new head of the Uganda delegation at its second session, he insisted that unless his territory gained the capital there would be no federation. Such a demand arose from Uganda's fear of being " the backwater of the proposed federation " ${ }^{18}$; the capital was required to offset the weakness arising from its landlocked location. At the final meeting of the Working Party, this question was moved to the bottom of the agenda and, after it proved impossible to reach agreement on other matters, the chairman decided that there was no point in discussing it further. Kenya and Tanzania might well have given in to Uganda on this matter had negotiations continued, but such a concession would not by itself have secured its acceptance of federation.

A second major stumbling block was the organisation of the federal parliament. Agreement was reached at an early stage that it should consist of two chambers-a House of Representatives with

17 Uganda National Assembly Debates, June 22, 1965, Tape No. 24, P. 4.

18 Uganda National Assembly, Official Report, June 26, 1964, col. 1934 (A. A. Nekyon). For a general discussion of the capital issue, see Aaron Segal, "Choosing a Federation Capital ", East Africa Journal, Vol. I (May 1964), pp. 2-7. 
seats distributed among the three territories in proportion to population and filled by direct elections, and a Senate in which each territory would have an equal number of members chosen by its own legislature. Such a structure was designed to provide some protection for Uganda which had a population of approximately seven million as compared with Kenya's eight and a half million and Tanganyika's nine and a half million. There were sharp differences, however, over the powers of the Senate at the second meeting of the Working Party. Uganda demanded that these must be at least as great as those of the House of Representatives and preferably greater. A strong Senate was needed, Mr. Nekyon argued, to balance the strong one-man executive, which Uganda had reluctantly accepted after its proposal of a collegial executive had been rejected, and to prevent Uganda from being overwhelmed in the legislative process by the more populous territories. The second chamber must, he insisted, consent to political appointments, approve treaties, and agree to all Bills before they became law. ${ }^{19}$ Kenya and Tanganyika maintained, on the other hand, that under such an arrangement "the states would overshadow the Federal Government, inhibiting the vigorous exercise of Federal powers, and upsetting the proper balance of the Constitution ". ${ }^{20}$ Neither side was prepared to compromise on this issue and it remained unsettled to the end.

Even more critical was the dissension which emerged over the division of powers between the central and unit governments. At the first session of the Working Party, agreement was reached "in broad outline", and the lawyers were told that a strong federation was desired. ${ }^{21}$ At the second meeting, however, Uganda came out forcefully in favour of a very weak central government, holding that the following subjects must remain under territorial control: mines, higher education, agriculture and marketing boards, livestock and animal husbandry, trade unions, external borrowing, citizenship and foreign affairs. Kenya and Tanganyika held initially that power over each of these matters must be ceded to the centre, but sufficient concessions were made on both sides to permit substantial agreement finally on all but the last two items. Kenya and Tanganyika maintained consistently that federation by definition required the centralisation of control over citizenship and foreign affairs. "Without these powers", said the latter, "there

19 Uganda National Assembly, Official Report, June 26, 1964, cols. 1940-41.

20 United Republic of Tanganyika and Zanzibar National Assembly, Official Report, June 23, 1964, col. 346 (O. S. Kambona).

21 Ibid. col. 345 (O. S. Kambona). 


\section{J. H. PROCTOR, JR.}

can be no question of a genuine political association." 22 Uganda denied this and charged the others with being mistaken in assuming that there was some standard federal model which must be followed in all cases. ${ }^{23}$

The Ugandan position was that citizenship of each territory should automatically confer East African citizenship, but that East African citizenship should not make one a citizen of the other territories. Mr. Nekyon explained that Uganda insisted on retaining control over citizenship because it wished to be able to restrict the interterritorial movement of persons. Uganda was afraid that its efforts to provide full employment and higher standards of living would be frustrated by a massive influx of Kenyans. ${ }^{24}$ Kenya with its problems of unemployment and land hunger, had a strong interest in guaranteeing freedom of movement; but Mr. Mboya indicated that his Government would, by way of compromise, consider arrangements by which the labour market of each territory might be protected "to some extent". ${ }^{25}$ That offer was not accepted by Uganda, however, and the question remained deadlocked.

Uganda was also adamant on keeping power over external relations. It was not prepared to lose its identity as a sovereign member of the international community and was particularly anxious to retain its separate representation in the United Nations. Mr. Nekyon argued that Uganda was prevented by its adherence to the Charter of the Organisation of African Unity from merging into a larger unit, for the preamble of that document asserted that signatories were "determined to safeguard and consolidate the hard-won independence as well as the sovereignty and territorial integrity of our states". Uganda was committed to the eventual federation of the African continent, he continued; if it surrendered foreign affairs to an East African Government now, what could it relinquish ultimately to that wider federation? He argued, moreover, that East Africa's strongest weapon in international affairs was its three separate voices and votes in the United Nations. Lacking any

22 "Government Statement on the East African Federation, June 1, 1964 ", loc. cit.

23 Uganda National Assembly, Official Report, June 26, 1964, cols, 1933, 1939-1940 (A. A. Nekyon).

24 Ibid. col. 1938 (A. A. Nekyon).

25 "Summary of the Meeting of the Working Party on East African Federation Held in Parliament House, Kampala, on Saturday 30th May, 1964 ", Meetings and Discussions on the Proposed East Africa Federation, p. 10. See also T. J. Mboya, "East African Labour Policy and Federation ", Federation in East Africa: Opportunities and Problems, ed. C. Leys and P. Robson (Nairobi: Oxford University Press, 1965), p. 104. 
THE EFFORT TO FEDERATE EAST AFRICA: A POST-MORTEM

significant military power, "we require", he said, "more voices to shout and be heard on the international scene ". ${ }^{26}$

Kenya and Tanganyika rejected these arguments altogether, holding that " unless the Federal Government was given exclusive control over foreign affairs we could not be said to have established a Federation at all ".27 Kenya was willing to go no further than to offer to explore ways of ensuring that the territories would have some share in the shaping of foreign policy-such as giving the Senate power to approve diplomatic appointments and according a prominent role to a Foreign Relations Committee of that body-but this overture evoked no response.

It is possible that Uganda was sincerely trying to find a formula for federation which would safeguard its interests adequately, feeling that the danger of its being outvoted by the other two territories was so great that the competence of the Federal Government must be held to the barest minimum. Many Kenyans and Tanganyikans were convinced, however, that its position on the division of powers really amounted to saying that it was not prepared to accept federation at all. Rather than reject the principle openly and directly, it may well have adopted the tactic of making demands which it knew to be unreasonable and unacceptable.

While the differences over the content of the constitution were obviously quite acute, an interpretation of the failure to federate East Africa simply in terms of these drafting difficulties would be naïve and inadequate. For one thing, the Working Party did not actually discuss the full range of problems involved in framing a federal constitution. It never got around to considering the financial aspects of political union, for example. This would in all probability have been a particularly troublesome matter to sort out, for Uganda was very much afraid that it would be required to pay a disproportionately large share of the costs of the Federal Government and possibly even to subsidise the other two territories. Its anxieties on this point were communicated by Dr. Obote to the other Heads of Government in a letter of September 29, $1963 .^{28}$ But a more important reason for looking beyond the deliberations of the Working Party is the fact that these constitutional disputes were merely superficial reflections of more basic underlying pressures and conflicts.

26 Uganda National Assembly, Official Report, June 26, 1964, col. 1937. See also cols.

27 United Republic of Tanganyika and Zanzibar National Assembly, Official Report, June 23, 1964, col. 347 (O. S. Kambona).

28 Uganda National Assembly, Official Report, July 3, 1964, col. 2188 (S. N. Odaka). 


\section{J. H. PROCTOR, JR.}

\section{III}

The difficulties seem to have been due in part to foreign interference. Dr. Nyerere warned a TANU conference in August 1963 that "outside people" were trying to undermine the federal effort ${ }^{29}$; and the Kenyan Finance Minister, Mr. J. S. Gichuru, told the CLA that "it was these outside influences which got in our way", when explaining why the deadline set in the Nairobi Declaration had not been met. "If we had been left alone, I am quite sure we would have done much more up to this moment", he added. ${ }^{30}$ Both of them declined to identify the sources of those external pressures, however.

Several Tanzanian M.P.s asserted that it was the colonialists and neo-colonialists who were responsible, and the TANU newspaper, The Nationalist, on June 23,1964, accused the United States and the United Kingdom in particular of intervening to prevent federation because East African unity would hasten the liquidation of white rule in Mozambique and Rhodesia. No tangible evidence was ever offered in support of these allegations, however.

\section{Ghana's Opposition}

A real source of external interference was Ghana. Dr. Nkrumah was openly opposed to regional federations in general, for he felt that they would impede the achievement of the continental unity which he favoured. "There is the danger", he wrote, "of the development of regional loyalties, fighting against each other." ${ }^{31}$ He was said to have charged covertly that East African Federation was a neo-colonialist plot designed to perpetuate Western exploitation of the area and to instal stooges of the West in more powerful positions. $^{32}$ Some of those who differed from Dr. Nkrumah suggested that his opposition really stemmed from the fear that an East African Federation would be too formidable a rival to Ghana for the leadership of all of Africa. In any event, the federal effort was bitterly condemned by the Government-controlled newspapers of Accra, and Ghanaian officials in East Africa engaged in "an unrestrained public diplomatic offensive " ${ }^{33}$ as well as clandestine

29 Daily Nation (Nairobi), August 20, 1963.

30 East African Common Services Organisation, Proceedings of the Central Legislative Assembly Debates, January 16, 1964, col. 1428.

31 Kwame Nkrumah, Africa Must Unite (London: Heinemann, 1963), p. 214.

32 Richard Cox, Pan-Africanism in Practice: An East African Study, PAFMECSA 19581964 (London: Oxford University Press, 1964), p. 76.

33 Thomas M. Franck, East African Unity through Law (New Haven: Yale University Press, 1964), p. 161 . 
THE EFFORT TO FEDERATE EAST AFRICA: A POST-MORTEM

"lobbying" ${ }^{34}$ against the project. Dr. Nkrumah himself sent messages directly to various East African leade $\mathrm{s}$ registering his disapproval of federation and urging them not to proceed with it.

The Ghanaian campaign was most active and most effective in Uganda. Several M.P.s there echoed Dr. Nkrumah's views when developing the case against federation in the National Assembly. Mr. S. N. Odaka, the Deputy Foreign Minister, said that he had been told by the representative of a powerful nation in Kampala that his Government would make available to Uganda ten times more aid than had previously been discussed if it would enter the federation. "I hope", he said, "that we will not willingly see neocolonialism of this nature dangled at us. ... I I will tell them that Uganda is perfectly ready and prepared to continue being poor but we will not sell ourselves to any country." ${ }^{35}$ The Minister of Housing and Labour, Mr. G. B. K. Magezi, reported that he had been impressed by evidence in the External Relations files that the Western embassies " have been more interested in our immediate federation than even ourselves" ${ }^{38}$ A variety of ulterior motives behind such interest was suggested in the parliamentary debatesthat federation would provide a large market for Western capitalists, would be a base from which neo-colonialist agents could operate, would create an economic entity too small to support industries which might compete with British and American firms, and would frustrate a wider and more powerful union. Dr. Nkrumah was cited explicitly in support of the argument that East African Federation must be rejected because it might delay the creation of a full-scale Pan-African Government.

While Ghana's attitude and activity probably contributed somewhat to the reluctance of the Ugandan Government to proceed with federation, it was not a major factor. The effect of external pressures generally was exaggerated by some East African leaders to save them from having to acknowledge the importance of other causes nearer home. Mr. John Kakonge, Uganda's Director of Planning and a member of the Working Party, put the matter in perspective when he said in June 1965, "The problems were clearly internal, and it would be a reflection on the sincerity of our leaders ... if they sought to absolve themselves from the failure to bring about unity by laying the blame on outside forces ". ${ }^{37}$

31 Cox, op. cit., p. 75.

35 Uganda National Assembly, Official Report, July 3, 1964, col. 2190.

36 Ibid. July 10, 1964, col. 2410 .

37 Uganda Argus, Junc 17, 1965. 
J. H. PROCTOR, JR.

\section{IV}

A basic internal problem was the growth of a separate nationalism in each of the three territories and an increasing tendency for them to give priority to local interests, rather than to the general East African interest, in their relations with each other.

\section{Separatist Trends}

This trend had actually appeared before the Nairobi Declaration, as evidenced particularly by the breakup of the East African Navy in 1962 and by Uganda's withdrawal from the East African Tourist Travel Association in February 1963. It seemed to become stronger in the months which followed. Ugandans complained more frequently that they were not getting a fair share of the benefits provided by EACSO, referring especially to the location of most of its offices and training schools in the Nairobi area and to the small number of Ugandans among those recruited and promoted by that Organisation. Friction also developed within the University of East Africa; the agreement to prevent duplication of professional faculties among the three constituent units broke down and Uganda resented decisions which seemed to hold its Makerere College back to allow the newer colleges to catch up with it. Stresses within the common market became more serious as manufacturing and commercial activity congregated increasingly around Nairobi and as Kenya's exports to Uganda and Tanganyika continued to be much greater than their exports to it; special arrangements were demanded to encourage industrialisation in the two less-developed territories and to redress the imbalance in their trade. The development of these conflicts and tensions led many Ugandans to be less enthusiastic about federation, for they felt that the selfish attitudes displayed by Kenya and Tanganyika and the dominating position of the former in these arrangements would only appear again-and more dangerously-within a federal union.

Relations between the three territories were also strained by their rivalry for investment capital and markets as they proceeded to develop their economies separately. Uganda took umbrage at the way in which the Kenyan and Tanganyikan development plans were drawn up. One of its representatives in the CLA told that body in January 1964 that it was those two territories which were delaying federation because each of them had planned, without consulting its neighbours, for the establishment of industries which 
THE EFFORT TO FEDERATE EAST AFRICA: A POST-MORTEM

already existed elsewhere in East Africa and had thereby opened the way to overproduction and wasteful competition. ${ }^{38}$

The primary commitment to narrow territorial interests also found expression in the deliberations of the Working Party itself. Mr. Nekyon described the tone of its meetings as follows:

We are negotiating now as independent states and when we sit at the conference table we talk as if we are talking at Geneva on disarmament. We are not talking on friendly terms as relations or as clans, but we are speaking as different states discussing their own future. . . We appreciate we are brothers but we will do everything in our power to see that Uganda gets her due share irrespective of our relations. ${ }^{39}$

The growth of such attitudes had been clearly foreseen by Dr. Nyerere in 1960 when he urged that federation should take place before the attainment of independence. It could hardly have been avoided once his proposal was rejected. The leaders of the newly independent states found it immediately necessary to strengthen the sense of national identity within each country if political stability was to be maintained, particularly in Kenya and Uganda where tribalism and separatism were acute problems. In mobilising loyalty around Kenyan or Ugandan leaders, institutions and symbols, however, they stimulated feelings which militated against federation. Moreover, the leaders themselves were impelled to behave nationalistically by the urgent demand for rapid economic development and social reform. Each one had to demonstrate in easily understandable terms his overriding concern for the problems and interests of his own electorate if he was to maintain popular support.

\section{Divergent Policies}

The prospects of federation were further reduced as the three territories developed somewhat divergent policies and as the difficulties in reconciling these came to be appreciated. In general, there was a tendency for Tanzania to move further and faster to the Left on both foreign and domestic issues.

In the realm of external affairs, all three professed to be nonaligned, but in the months following the Nairobi Declaration Tanganyika seemed to be leaning much more towards the East than were the other two, especially after its union with Zanzibar. This caused considerable concern in Uganda and Kenya; Dr. J. G. Kiano, the Kenyan Minister for Commerce and Industry, said in August 1964 that certain fundamental problems must be solved before

38 EACSO, Proceedings of the CLA Debates, January 16, 1964, cols. 1422-1424 (S. Nyanzi). 39 Uganda National Assembly, Official Report, July 12, 1963, col. 1046. 


\section{J. H. PROCTOR, JR.}

federation, and that in particular " people will also have to agree on the true meaning of political non-alignment ". ${ }^{40}$ The rift widened during the following year, however.

Domestically, there were significant dissimilarities in policies regarding economic development as well as labour. Tanganyika seemed to many Kenyans and Ugandans to be proceeding along more extremely socialistic lines in the planning of its economy than were their territories. Mr. Ali Kisekka of Uganda told the CLA that this made federation difficult; "I do not know how we East African countries could co-ordinate our economic policies when we have this sort of difference", he said. ${ }^{41}$ The subjection of Tanganyika's trade union movement to strict Government control produced anxiety elsewhere in East Africa. Mr. Nekyon said that it was the unacceptability of Tanganyika's labour legislation and the fear that it might spread throughout the area in the event of federation which caused Uganda to insist that authority over trade unions must not be surrendered to the centre. ${ }^{42}$ Others regarded the Tanganyikan legislation as a bar to federation altogether. Mr. Humphries Luande, President of the Uganda Trade Union Congress, served notice that he would oppose federation so long as that system of control continued, ${ }^{43}$ and a meeting of trade union leaders in Kenya resolved that Tanganyika must bring its laws into line with Kenya's Industrial Charter before federation would be acceptable. ${ }^{44}$

Certain aspects of the Tanzanian political system also had a deterrent effect. Ugandan Ministers and backbenchers were critical particularly of the reorganisation of the Tanganyikan army on a political basis following the mutiny, the lack of elections in Zanzibar after the revolution, the existence of only one party, and the precariousness of civil liberties. Mr. Magezi alluded to the last of these when he told the Assembly that " the political ideology of Tanganyika and Zanzibar has made things more difficult for the East African Federation to come about quickly ". ${ }^{45}$

\section{Personal Interests and Federation}

Many East Africans believe that a major share of the blame for the failure of the federal effort must be laid at the feet of certain leaders

40 Mombasa Times, August 7, 1964.

11 EACSO, Proceedings of the CLA Debates, May 22, 1964, cols, 219-220.

42 Uganda National Assembly, Official Report, June 26, 1964, col. 1940.

$\$ 3$ Roger D. Scott, "Labour Legislation and the Federal Issue", East Africa Journal, Vol. I (November 1964), p. 26.

44 East African Standard, August 12, 1963.

45 Uganda National Assembly, Official Report, July 10, 1964, col. 2412. 
THE EFFORT TO FEDERATE EAST AFRICA: A POST-MORTEM

who were afraid that their own status might be reduced if it succeeded. They were said to prefer to remain "big fish in little ponds".

Generally this charge was levelled not against the heads of Government but against their Ministers and other "junior leaders" who realised, it was said, that their high posts in the territorial Governments would disappear as a result of federation and were not sure of securing seats in the Federal Cabinet. Neither Dr. Nyerere nor Mr. Kenyatta was vulnerable to such accusations, for the former was an ardent federalist and the latter was certain to be offered the top position in the Federal Government. The reluctance of Dr. Obote was said by some to be due to his awareness that he would be doomed to a distinctly secondary position at the federal level since the other two Heads of Government so clearly surpassed him in stature.

These accusations must be discounted at least in part because they were so often made by Opposition members seeking to discredit the Government by suggesting that Ministers were being guided primarily by their own personal interests. Such a purpose was not always present, however. Mr. Joseph Murumbi, for example, expressed his conviction in October 1963 that the difficulty in Uganda arose essentially from the fears of the leadership there. "Some of the Uganda leaders feel they might become nonentities overnight", he said. ${ }^{47}$ Two Tanzanian Ministers indicted Kenya's "junior leaders" as well in similar terms, ${ }^{48}$ and Uganda's Director of Planning said in June 1965 that he was convinced after examining all the possible obstacles to unity that the attitude of the leaders was the basic one and that unless they became willing to sacrifice their personal ambitions and privileges, federation would never be achieved. ${ }^{49}$

\section{V}

The problems encountered in the effort to federate East Africa were internal not only in the sense that there were genuinely indigenous interterritorial conflicts and tensions, but also in that difficulties existed within Uganda and Kenya which prevented their leaders from proceeding quickly to federation. Differences had to be resolved among various groups inside these territories as well as

46 Uganda National Assembly Debates, June 21, 1965, Tape No. 24, p. 3 (Abu Mayanja). 47 East African Standard, October 25, 1963.

48 United Republic of Tanganyika and Zanzibar National Assembly, Official Report, June 23, 1964, cols. 334-335 (C. G. Kahama); CLA meeting of May 19, 1965, as reported in Daily Nation, May 20, 1965 (M. M. Kamaliza).

49 Uganda Argus, June 17, 1965. 


\section{J. H. PROCTOR, JR.}

between the territories, and the question of federation could not be dissociated from the struggle for power domestically.

\section{Buganda's Attitude}

A major problem which faced Dr. Obote was the attitude of Buganda, the most important of the political subdivisions in Uganda. A proud and well-organised kingdom ruled by the hereditary Kabaka, it enjoyed a semi-autonomous position under the Ugandan Constitution, exercising extensive powers which could not be altered without its consent. Buganda had traditionally been wary of East African Federation for fear that such an arrangement would jeopardise its privileged status, and as recently as January 26, 1963, its legislature, the Lukiko, had passed a resolution opposing political union.

Five days after the Nairobi Declaration, a closed session of the Lukiko was presented by the Kabaka's Cabinet with a statement of policy which viewed East African Federation with favour on condition that Buganda be one of its constituent units. This was said to be necessary to guarantee the future not only of its monarchy and other traditional institutions but also of its very identity. The Lukiko authorised the Kabaka's Ministers to open talks with the Uganda Government on federation, but declined to take a stand on the issue itself until the terms of the constitution became available.

The Working Party immediately requested an audience with the Kabaka and on June 13 was received by him in his palace. Mr. Mboya said afterwards that everyone present obviously wanted unity and that "there are no big problems to be surmounted ". ${ }^{\text {so }}$ It was deemed desirable, nevertheless, to arrange a meeting between the three heads of Government and the several hereditary rulers of Uganda at the end of the month. Messrs. Kenyatta and Mboya arrived in Kampala early enough to join Dr. Obote in addressing a public rally on June 29 at which the anti-federalists were criticised in such a way as to offend Buganda. The Kabaka did not appear at the meeting with the heads of Government two days later, due, according to his spokesman, to the fact that at the last minute it had been shifted from his palace to the Uganda Parliament Building. Dr. Obote's office replied that there had been no change in the place but only in the time of meeting and that the Kabaka's secretary had been notified well in advance. This "misunderstanding" led reporters to speculate on the possibility that serious difficulties

50 lbid. June 14, 1963. 
THE EFFORT TO FEDERATE EAST AFRICA: A POST-MORTEM

had arisen, but Mr. Mboya assured them that there was no significance in the Kabaka's failure to attend the talks and no threat to the chance of reaching speedy agreement. ${ }^{51}$

The Kabaka's Ministers did meet with Dr. Obote at about this time, however, to express regret that he had signed the Nairobi Declaration without consulting them and to ask what the federal constitution would provide. The Prime Minister replied, according to a Buganda Government statement, that he had not even consulted his own Cabinet before going to Nairobi, that the Declaration did not definitely commit Uganda to federation, and that he could not say what the constitution would look like until the Working Party had completed its draft. ${ }^{52}$ In an effort to reassure Buganda publicly, he told the Ugandan National Assembly that " if this federation is to come into being, it would be necessary to come to this House, and possibly to go to other legislatures, to amend certain sections of our Constitution ". ${ }^{53}$

The Uganda Government was completely unwilling to accept Buganda's demand that it be allowed to enter the federation as a separate constituent unit, and its Minister of Justice rejected the idea publicly on August 22, $1963 .{ }^{54}$ To have accepted that demand would have meant the division if not liquidation of Uganda, and the Government was not prepared to pay such a price to achieve federation. To have pressed towards the establishment of a federal government without concession to Buganda on this point would have been to risk the downfall of the Obote Government, for it rested upon an alliance between the Uganda People's Congress (UPC) and the Buganda party known as Kabaka Yekka (KY). Such action would also have threatened the very unity of Uganda itself. Dr. Obote therefore felt compelled to proceed very cautiously indeed. He asked the leaders of Kenya and Tanganyika to give him time "to consolidate his political position" when they urged him to meet with them in an effort to break the deadlock in the Working Party, according to Mr. Kambona ${ }^{55}$; and he explained to the delegation from the backbenchers' conference, according to one of its members, that he could not take Uganda into federation immediately because it would be "practically impossible" for him to secure

51 East African Standard, July 3, 1963.

52 Uganda Argus, July 3, 1963. For substantiation of the point that Dr. Obote had not consulted his Cabinet, see Uganda National Assembly, Official Report, July 10, 1964, col. 2430 (B. K. Kirya).

53 Uganda National Assembly, Official Report, July 2, 1963, col. 734.

54 Uganda Argus, August 23, 1963.

55 Pan-Africa (Nairobi), May 15, 1964, p. 22. 


\section{J. H. PROCTOR, JR.}

the necessary majorities in the National Assembly and in the Lukiko. ${ }^{56}$

While the problem of Buganda does seem to have been a major factor in shaping the Ugandan position on federation, it must not be accepted as the sole explanation. Some have held, in fact, that the Government had decided to withdraw from the federal movement for other reasons altogether and was using Buganda as "an alibi ". ${ }^{57}$

\section{Tribal Resistance in Kenya}

The domestic political situation also affected to some extent Kenya's behaviour regarding federation. That territory advanced to independence with a constitution which allocated considerable power to the seven regions or majimbo into which it was divided. Such a decentralised pattern had been demanded by the Kenya African Democratic Union (KADU), for the smaller tribes which supported that party saw in it a protection against domination by the larger and more advanced tribes. The general election of May 1963 was won by KANU, a party based primarily on the Kikuyu and Luo tribes which considered this constitution too cumbersome for effective government and was eager to reduce materially the status of the regions.

KADU leaders welcomed the Nairobi Declaration, but insisted that power must be surrendered to the federation only at the expense of the central Government of Kenya; there must be no tampering with the authority of the regions. Indeed, they held that the regions should be the constituent units in the East African Federation and that Kenya as such should be eliminated. ${ }^{58}$

KANU was unalterably opposed to this idea; it maintained that both the territorial and regional governments must relinquish power and that Kenya must enter the federation as a unified-and more centralised-whole. $^{59}$ On June 17, 1964, Mr. Kenyatta told the House of Representatives that " if it was not for a KADU nuisance we would have federated a long time ago.... If it was not for the introduction of majimbo by KADU, the Federation would have

56 Kenya House of Representatives, Official Report, June 17, 1964, col. 284 (Z. N. Anyieni). 57 Uganda National Assembly Debates, June 21, 1965, Tape No. 24, p. 3 (Abu Mayanja). See also Tape No. 25, p. 4.

58 Kenya House of Representatives, Official Report, June 25, 1963, cols. 310 (M. Muliro), 324 (J. K. ole Tipis); June 27, 1963, cols. 405-407, 428-429 (R. G. Ngala); August 2, 1963, col. 1700 (R. G. Ngala); Kenya Senate, Official Report, July 4, 1963, col. 170 (N. W. Munoko).

59 Kenya House of Representatives, Official Report, June 27, 1963, cols. 413, 416-417 (T. J. Mboya), $418-420$ (J. G. Kiano); August 2, 1963, col. 1671 ('T. J. Mboya); Kenya Senate, Official Report, July 9, 1963, col. 260 (J. P. Mathenge). 
THE EFFORT TO FEDERATE EAST AFRICA: A POST-MORTEM

been much easier." $\mathrm{He}$ asserted categorically that the existing constitution would have to be scrapped before federation would be possible; "We cannot have a majimbo Federation", he said. ${ }^{60}$

There were those who argued that majimbo was being made the scapegoat in the affair, that the need to amend the constitution was merely a pretext for delay which was actually due to very different reasons. The Leader of the Opposition termed Mr. Kenyatta's explanation "a very lame excuse", and called attention to the fact that the account of the Working Party talks released by the United Republic had contained no indication whatever that majimbo was a snag. ${ }^{61}$ The KADU view was that the Government was dragging its feet on the matter because the Kikuyu were afraid that their influence would be much less on the East African level than it was within Kenya alone.

\section{Party Politics as an Adverse Factor}

Another domestic consideration which seems to have obstructed the attainment of federation was the concern of some leaders over its possibly adverse effect on their position in party politics at home. The Opposition in Uganda charged that Dr. Obote and his friends were unenthusiastic about federating because they feared that if they went away to the federal capital their party might split into warring factions with unforeseeable consequences. ${ }^{62}$ The point was developed more broadly - and more authoritatively-by Mr. Grace Ibingira, Minister of State in the Uganda Government, when he explained the failure of the federal effort as follows:

... The leaders are conditioned in their actions and thinking by developments in their Party ranks and the ever-present problems inherent in jostling for position in the Party machine. ... This detracts the attention of the leaders who become constantly engaged in discovering and exploring tricks or coups, real or imaginary, in their Party ranks. Both consciously and unconsciously they turn to be inward-looking. The prospects of federal union then become a vast darkness, crowded with uncertainties and potential rivals. . . . In apportionment of responsibility ... I am compelled, sadly but inexorably, to conclude that the fault is embedded in the power mechanics of the three main Parties-KANU, TANU, UPC. ${ }^{63}$

This may well have been a major factor in shaping the attitude of the Kenya Government, especially after the admission of extremely Leftist elements to the United Republic Cabinet, for Mr. Mboya had

60 Kenya House of Representatives, Official Report, June 17, 1964, cols. 269-271.

61 lbid. June 18, 1964, col. 329.

62 Uganda National Assembly, Official Report, July 10, 1964, cols. 2429-2430.

63 Reporter (Nairobi), July 2, 1965, p. 10; Uganda Argus, June 19, 1965. 


\section{J. H. PROCTOR, JR.}

reason to fear that union with such a Government would serve to strengthen the position of his principal antagonist in KANU, Mr. Oginga Odinga.

\section{VI}

As one looks back over what has happened since the Nairobi Declaration, one wonders how the three heads of Government could possibly have believed then that a federation could be brought into being within seven months. The number and complexity of the problems involved in the mere drafting of a federal constitution were so great that it was quite unrealistic to expect the Working Party to present a final report in ten weeks. Moreover, the three leaders could hardly have been unaware of the enormous underlying obstacles which existed and of how far they actually were from the substantial agreement on fundamentals which is the prerequisite of successful federal negotiations.

It is possible that they somehow underestimated the difficulties and that unanticipated impediments were encountered after the drafting got under way which made it impossible to reach a mark that had been set in good faith. Such an interpretation was offered by Mr. Ibingira when he told the Ugandan National Assembly in June 1965 that at the time of the Nairobi Declaration "there was no question of problems being visualised which could not be surmounted, everything at that time seemed and appeared to be possible . ..., but various factors, known and unknown, hidden or exposed, came ... to frustrate the movement ...".64

A more plausible interpretation is that the leaders-or at least some of them-actually had no serious intention to federate by the end of 1963, if at all, and that the Nairobi Declaration and the motions through which the Working Party went were designed in fact to serve primarily some other purpose than to carry the federal movement forward.

\section{Was the Nairobi Declaration a Ruse?}

A strong case can be made for the proposition that the whole exercise was largely a ruse designed to hasten Kenya's independence. The British were known to be very eager for an East African Federation, and they were assured by the three heads of Government at Nairobi on June 5, 1963, that it would be established in short order if Kenya were granted its freedom first. Their Declaration read:

64 Uganda National Assembly Debates, June 29, 1965, Tape No. 9, p. 2. 
THE EFFORT TO FEDERATE EAST AFRICA: A POST-MORTEM

We must declare most strongly our opposition to : ny attempt to delay the country's achievement of Independence any longer. . . . We are closely involved in this matter now, since a hold-up in Kenya's advance to Independence will hinder the achievement of Federation to which we are committed. The three Governments, having agreed to the establishment of a Federation this year, expect the British Government to grant Kenya's Independence immediately. ${ }^{65}$

The East Africans had good reason to believe that Britain would not delay relinquishing sovereignty in Kenya if it were convinced that to do so would be to obstruct the realisation of federation.

Just after the first meeting of the Working Party, Mr. Mboya headed a delegation to London to press the Kenyan demands. $\mathrm{He}$ described the accomplishments of that meeting to Mr. Duncan Sandys, the Secretary of State for Commonwealth Relations and for Colonies, and secured from him a commitment to convene a Kenya Independence Conference in September and to transfer power finally on December 12. When Mr. Sandys informed the House of Commons of these arrangements, he said that the decision to federate was " an important new development ... . which has to be taken into account in the timing of Kenya's independence". The three Governments had affirmed their intention to establish the federation before the end of the year and had "already made substantial progress in working out the constitution ", he added; and it was "in the light of these considerations" that such an early date had been set. ${ }^{66}$

If this was in fact the purpose which the Nairobi Declaration was primarily intended to serve, certain rather puzzling aspects of the federal movement become more understandable. This would explain why it was that what seemed like such an important commitment could have been signed at a brief and hurriedly arranged meeting which was not preceded by any significant preliminary negotiations on the subject nor-at least in the case of Uganda-by Cabinet discussions; it was not really a commitment at all. It would also explain the abrupt change in Uganda's position between the first and second meetings of the Working Party. That first session may well have been regarded by Uganda less as an occasion for genuine bargaining than as a means of benefiting Mr. Mboya's mission to London by convincing the British that the East Africans were in earnest and that the promised deadline would be met. Once the date of Kenya's independence had been set, Uganda could put

65 "The Federation Declaration of 5th June, 1963", Federation in East Africa, ed. Leys and Robson, Appendix I, p. 207.

66 United Kingdom, Parliamentary Debates (Commons), Vol. 680, July 2, 1963, col, 201. 


\section{J. H. PROCTOR, JR.}

forward its objections and demands which were so far-reaching as to raise serious doubts about the possibility of implementing the Nairobi Declaration. It would explain, finally, Mr. Mboya's deliberately concealing the difficulties which arose in the Working Party and his misleadingly optimistic statements to the Press; the show of unity must be maintained as long as possible to avoid complications and embarrassment in the preparations for the transfer of power.

Apart from this circumstantial evidence, there is also the testimony of the East African leaders themselves to support such an interpretation. After Kenya was safely free, various Ugandan Ministers began to express some surprise and irritation that certain Tanganyikans and Kenyans should still be pressing them to federate. Dr. Obote told the delegation from the backbenchers' conference in May 1964, when explaining his unwillingness to take the steps they demanded, that "the idea of Federation had been put forward as an argument to speed Kenya's independence" ${ }^{67}$; and Mr. A. K. Sempa, his Finance Minister, said in the CLA that same month: "I think it is wrong that hon. Members should keep on quoting this June Declaration. ... The whole thing was to induce the British people to set Kenya free " ${ }^{68}$ Dr. Obote repeated this version after the subsequent passage of pro-federation resolutions by the Tanganyikan and Kenyan Parliaments; he could not understand why they had done so, he said, since "the first objective of the [Nairobi] meeting was to achieve Kenya's independence-regardless of what people today were alleging ". ${ }^{69}$

One might suspect Uganda of inventing this interpretation in order to excuse itself for backing out-on second thoughts-of a movement which had actually been sincerely launched, were it not for the substantiation provided later by Mr. Kenyatta himself. Speaking to a rally at Kisumu on August 2, 1964, he boasted of how he had deceived the British in the matter. He had asked Drs. Nyerere and Obote to sign the Nairobi Declaration, he said, because he understood that independence would be granted more quickly if they agreed to federate. The British had asked him whether he was confident that a federal government could be created by the end of the year, he continued, and after he had replied affirmatively they invited a Kenya delegation to London for talks on independence. When the British had questioned his sincerity after the federation

67 Uanda Argus, May 11, 1964.

68 EACSO, Proceedings of the CLA Debates, May 29, 1964, col. 487.

69 Uganda Argus, June 27, 1964. 
THE EFFORT TO FEDERATE EAST AFRICA: A POST-MORTEM

failed to materialise, he had replied, "That was diplomacy". $\mathrm{He}$ then called upon the crowd to applaud Drs. Nye ere and Obote for their co-operation in accelerating Kenya's independence by this "master plan ". " A spokesman for the Prime Minister objected that it was a mistranslation to quote him as having said the Declaration was a "trick", as one of the Nairobi newspapers had done; the Swahili word he used actually meant "ingenuity", he explained. ${ }^{71}$

Among those fooled by this manoeuvre were not only the British, but also many East Africans, including quite possibly Dr. Nyerere. A State House spokesman in Dar es Salaam asserted after Mr. Kenyatta's disclosures at Kisumu that the President had signed the Declaration " in all honesty, believing that federation was genuinely wanted ". ${ }^{2}$

\section{An Unfortunate Episode}

To those who genuinely champion federalism in East Africa, its involvement in the "diplomacy of independence" must appear in retrospect to have been unfortunate, for this caused the federal negotiations to be undertaken prematurely and in such a way as virtually to ensure their failure. From the standpoint of Kenyan independence, it was desirable for work on a federal constitution to be initiated in June 1963 at the ministerial level, abruptly, and under pressure of a tight deadline; but from the standpoint of East African federation, this was disastrous. Disputes soon arose which drove the three Governments far apart, differences hardened, and permanent deadlock ensued. This might have been avoided had there first been more discussion of the case for federation within the three Cabinets and Parliaments, some acceptance of the general principle by those bodies, and some informal exploration of the problems involved in framing a federal constitution, preferably with the aid of experts. To engage in the essentially artificial and futile exercise of attempting to draft a federal constitution in the absence of a real readiness to federate or even a clear understanding of what federation involved, could only do harm to the cause of federalism. The confusion and cynicism which have resulted from this fiasco do not provide an atmosphere conducive to the resuscitation of the federal movement within the foreseeable future.

10 East African Standard, August 3, 1964; Daily Nation, August 3, 1964.

71 Daily Nation, August 5, 1964.

72 Tanganyika Standard, August 4, 1964. 